Article

\title{
Copper-Modified Zeolites and Silica for Conversion of Methane to Methanol
}

\author{
Xueting Wang ${ }^{1}\left(\mathbb{D}\right.$, Natalia M. Martin ${ }^{1}{ }^{\circledR}$, Johan Nilsson ${ }^{1}$, Stefan Carlson ${ }^{2}$, Johan Gustafson ${ }^{3} \mathbb{(}$, \\ Magnus Skoglundh ${ }^{1}$ (D) and Per-Anders Carlsson ${ }^{1, *(D)}$ \\ 1 Department of Chemistry and Chemical Engineering and Competence Centre for Catalysis, \\ Chalmers University of Technology, 41296 Gothenburg, Sweden; wangxu@chalmers.se (X.W.); \\ natalia.martin@chalmers.se (N.M.M.); johan.nilsson@chalmers.se (J.N.); skoglund@chalmers.se (M.S.) \\ 2 MAX-IV Laboratory, Lund University, 22100 Lund, Sweden; Stefan.Carlson@maxiv.lu.se \\ 3 Synchrotron Radiation Research, Lund University, 22100 Lund, Sweden; johan.gustafson@sljus.lu.se \\ * Correspondence: per-anders.carlsson@chalmers.se; Tel.: +46-31-772-29-24
}

Received: 27 September 2018; Accepted: 12 November 2018; Published: 15 November 2018

check for updates

\begin{abstract}
Powder materials containing copper ions supported on ZSM-5 (Cu-Zeolite Socony Mobil-5) and SSZ-13 (Cu-Standard Oil synthesised zeolite-13), and predominantly $\mathrm{CuO}$ nanoparticles on amorphous $\mathrm{SiO}_{2}$ were synthesised, characterised, wash-coated onto ceramic monoliths and, for the first time, compared as catalysts for direct conversion of methane to methanol (DCMM) at ambient pressure (1 atm) using $\mathrm{O}_{2}, \mathrm{~N}_{2} \mathrm{O}$ and $\mathrm{NO}$ as oxidants. Methanol production was monitored and quantified using Fourier transform infrared spectroscopy. Methanol is formed over all monolith samples, though the formation is considerably higher for the copper-exchanged zeolites. Hence, copper ions are the main active sites for DCMM. The minor amount of methanol produced over the $\mathrm{Cu} / \mathrm{SiO}_{2}$ sample, however, suggests that zeolites are not the sole substrate that can host those active copper sites but also silica. Further, we present the first ambient pressure in situ infrared spectroscopic measurements revealing the formation and consumption of surface methoxy species, which are considered to be key intermediates in the DCMM reaction.
\end{abstract}

Keywords: methane partial oxidation; DCMM; supported copper ions; methoxy reaction intermediate species; in situ infrared spectroscopy; $\mathrm{Cu}-\mathrm{ZSM}-5$; $\mathrm{Cu}-\mathrm{SSZ}-13 ; \mathrm{Cu} / \mathrm{SiO}_{2}$

\section{Introduction}

Methane is the main component in natural gas, which attracts much attention as an abundant hydrocarbon source. In some regions, methane from renewable sources, biomethane or biogas, is becoming increasingly available as well. Renewable methane is beneficial as a green drop-in fuel or chemical feedstock that can increase industrial sustainability. To make use of methane in practice, however, it is often beneficial to convert it to a liquid compound as to increase the energy density, and facilitate distribution and storage. One strategy is to make methanol through partial oxidation of methane. Methanol is one of the industrial platform chemicals that also has the advantage of being biodegradable [1]. Present industrial methanol production from methane is an energy intensive process carried out in two steps: partial oxidation of methane to syngas $\left(\mathrm{H}_{2}\right.$ and $\left.\mathrm{CO}\right)$ at elevated temperature followed by catalytic conversion of syngas to methanol at high pressure. The process infrastructure is costly and therefore direct conversion of methane to methanol (DCMM), preferably at low temperature, is an attractive alternative with lower energy loads and potentially cheaper installation costs. This solution, however, faces great challenges as both oxygen and methane are difficult to activate for catalytic partial oxidation, whereas methanol, once formed, may easily undergo further unwanted reactions that ruin the selectivity. 
Methane monooxygenases (MMOs) are naturally occurring enzymes that have the ability to selectively oxidise methane to methanol under ambient conditions [2]. The active sites of MMOs are di-iron [3] or di-copper centres [4] in a peptide ligand environment. Inspired by the structure and chemical functionality of MMOs, copper exchanged zeolites are considered to be inorganic analogues to the MMOs with respect to functionality of the copper sites [5-7]. To produce methanol over copper zeolites, however, a quasi-catalytic reaction sequence is commonly employed. In this approach, an oxidative activation of the copper zeolite at high temperature is required before methane can be oxidised at a lower temperature. Subsequently, methanol is released from the catalyst upon extraction using water, ethanol or other solvents. Although this activation-reaction-extraction sequence can be avoided under some certain conditions [8,9], the catalytic activity requires to be significantly improved in order to be industrially relevant for DCMM.

With the aim to design more efficient catalysts based on copper zeolites, much efforts have been put into identifying the active sites for this reaction both experimentally $[5-7,10-13]$ and theoretically [12-16]. Early studies suggest that the so-called $\alpha$-oxygen in iron complexes (analogue to the di-iron centres in the $\alpha$ subunit of MMO [17]) is the key to methane activation [18]. Similarly, copper dimers have been proposed to be the necessary sites for hosting the reactive oxygens for methane activation $[7,11]$. Later studies, however, indicate that different types of copper species, i.e., copper monomers [16], copper dimers [6,10,12], copper trimers [13] or small copper clusters [19] in zeolites, can catalyse the partial oxidation of methane to methanol. The variety of active copper species should in principle bring increased flexibility to the catalyst design as an advantage. It is, however, not clear if the requirement for active copper sites can be generalised and applied more broadly for catalyst synthesis, i.e., zeolite-free systems. Therefore, it is of great interest to comparatively investigate materials containing different types of copper species. Moreover, unlike many other metal-zeolite reaction systems, no reaction intermediates, presumably such as surface-bound methyl or methoxy groups [20], have been directly observed for copper-modified small-pore zeolites under DCMM reaction conditions.

In the present work, we investigate materials containing copper ions supported on ZSM-5 (Cu-Zeolite Socony Mobil-5 [21]) and SSZ-13 (Cu-Standard Oil synthesised zeolite-13 [22]), as well as predominantly $\mathrm{CuO}$ nanoparticles on amorphous $\mathrm{SiO}_{2}$, for direct oxidation of methane to methanol and use in situ infrared spectroscopy to monitor formation/consumption of surface species that play a role in the methanol formation. Methanol production over $\mathrm{Cu}$-zeolites and $\mathrm{Cu} / \mathrm{SiO}_{2}$ is detected over coated monolith samples for the first time. We report that DCMM occurs over copper ions and that these copper species exist on silica but are more abundant in zeolite structures. We present-under ambient pressure-the formation/consumption of mechanistically important methoxy species over $\mathrm{Cu}-\mathrm{ZSM}-5, \mathrm{Cu}-\mathrm{SSZ}-13$ and $\mathrm{Cu} / \mathrm{SiO}_{2}$ during DCMM.

\section{Results and Discussion}

\subsection{Methanol Production}

Figure 1 presents the amount of produced methanol over the Cu-ZSM-5, Cu-SSZ-13 and $\mathrm{Cu} / \mathrm{SiO}_{2}$ sample. As can be seen in the figure, methanol is produced over all samples during the extraction step. Methanol production, however, for Cu-ZSM-5 (regardless of oxidant) and Cu-SSZ-13 $\left(\mathrm{O}_{2}\right.$ or $\left.\mathrm{N}_{2} \mathrm{O}\right)$ is clearly higher than that for $\mathrm{Cu} / \mathrm{SiO}_{2}$ or H-ZSM-5 (not shown), which is negligible. Interestingly, the use of different oxidants for the activation step results in similar amounts of formed methanol during extraction for the Cu-ZSM-5 sample whereas for the Cu-SSZ-13 sample, the methanol formation is clearly dependent on the oxidant. For Cu-ZSM-5, DCMM reaction has been correlated (only) with the mono( $\mu$-oxo)dicupric site as characterised by the absorption band at $22,700 \mathrm{~cm}^{-1}$ in UV-vis spectrum $[6,10]$. Thus, it seems from the present results that this site can be activated by different oxidants. On the contrary, multiple absorption features in the UV-vis $[9,23]$ and Raman $[24,25]$ spectra have been reported for $\mathrm{O}_{2} / \mathrm{N}_{2} \mathrm{O}$ activated Cu-SSZ-13, which is indicative of the presence of various 
$\mathrm{Cu}$ species active for DCMM. Moreover, the observed $\mathrm{UV}$-vis bands after $\mathrm{O}_{2}$ and $\mathrm{N}_{2} \mathrm{O}$ activation [9] differs, suggesting that each oxidant activates distinct $\mathrm{Cu}$ species. This may be the reason for the different amounts of formed methanol observed here when using $\mathrm{O}_{2}$ or $\mathrm{N}_{2} \mathrm{O}$.

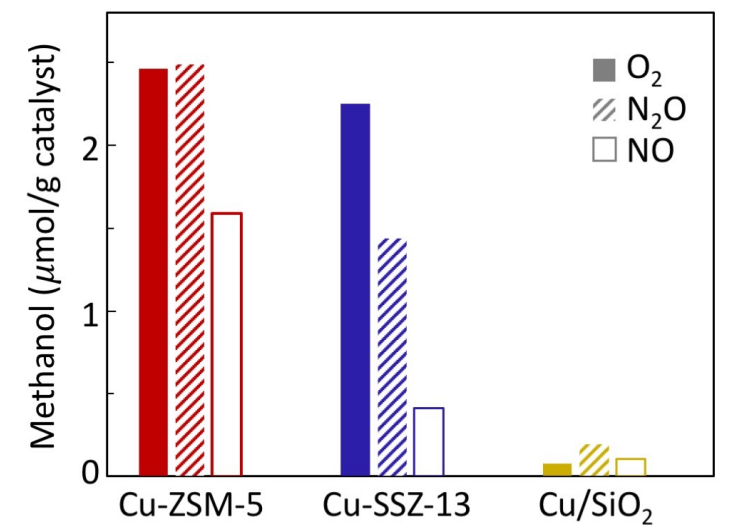

Figure 1. Methanol production over Cu-ZSM-5, Cu-SSZ-13 and $\mathrm{Cu} / \mathrm{SiO}_{2}$ at 1 atm using $\mathrm{O}_{2}, \mathrm{~N}_{2} \mathrm{O}$ or $\mathrm{NO}$ as oxidants.

\subsection{Catalyst Characterisation}

In Figure 2a, the XANES spectra of Cu-ZSM-5, Cu-SSZ-13 and Cu foil at the Cu K-edge are shown. The spectra of Cu-ZSM-5 and Cu-SSZ-13 overlap with each other. No obvious pre-edge peak for $\mathrm{Cu}(\mathrm{I})$ (well defined peak at $8982-8984 \mathrm{eV}[26,27]$ ) or pre-edge shoulder for metallic $\mathrm{Cu}$ (Figure 2a, black spectrum) can be observed. Both spectra present a sharp absorption at about 8995-8998 eV. This is due to the $1 s$-to- $4 p$ electronic transition of $\mathrm{Cu}$ (II) species [26], indicating that the dominating oxidation state of the copper species is $\mathrm{Cu}(\mathrm{II})$ in both copper zeolite samples. The featureless pre-edge, however, signifies the absence of $\mathrm{CuO}$ species (weak absorption at about $8976-8979 \mathrm{eV}$ and a shoulder at about 8985-8988 eV [27]), indicating that the Cu-ZSM-5 and Cu-SSZ-13 samples do not contain detectable amounts of large $\mathrm{CuO}$ domains. The spectrum of the $\mathrm{Cu}$ foil presents an evident pre-edge feature around $8983 \mathrm{eV}$ with resonance features above the edge that are clearly different from the spectra of $\mathrm{Cu}-\mathrm{ZSM}-5$ and Cu-SSZ-13. Figure 2b presents the Fourier transforms of the $\mathrm{Cu}$ K-edge EXAFS spectra of the Cu-ZSM-5 and the Cu-SSZ-13 sample as well as that of the reference compounds: $\mathrm{Cu}, \mathrm{Cu}_{2} \mathrm{O}$ and $\mathrm{CuO}$. Both Cu-ZSM-5 and Cu-SSZ-13 sample exhibit an intensive peak at around $1.5 \AA$, associated with the neighbouring $\mathrm{O}$ atoms. The absence of peaks at the range of $2.5-3 \AA$, suggesting the lack of neighbouring $\mathrm{Cu}$ atoms, indicating that isolated $\mathrm{Cu}$ ions are the dominant $\mathrm{Cu}$ species in these samples. Moreover, the calculated $\mathrm{Cu} / \mathrm{Al}$ ratio of the $\mathrm{Cu}-\mathrm{ZSM}-5$ and $\mathrm{Cu}-\mathrm{SSZ}-13$ sample is 0.38 and 0.14 respectively. At such ion-exchange levels, Cu dispersion is 100\% in ZSM-5 [28] and the Cu species in SSZ-13 are dominantly monomers [29].

In Figure 2c, the XRD patterns of the Cu-ZSM-5, Cu-SSZ-13 and $\mathrm{Cu} / \mathrm{SiO}_{2}$ samples are shown. The XRD patterns of the Cu-ZSM-5 and Cu-SSZ-13 samples exhibit only characteristic peaks of the respective zeolite structure [30] (the XRD patterns of the parent zeolites are presented in the Supplementary Materials Figure S1), while no reflections of crystalline $\mathrm{Cu}$ species are visible. This suggests that the $\mathrm{Cu}$ species in these samples are smaller than 2-3 nm. Additional $\mathrm{CO}$ and NO adsorption experiments shown in the Supplementary Materials Figure S2 confirm the presence of cationic copper species in both the Cu-ZSM- 5 and the Cu-SSZ-13 sample. For the diffractogram of the $\mathrm{Cu} / \mathrm{SiO}_{2}$ sample, reflections characteristic of crystalline $\mathrm{CuO}$ are evident, indicating the existence of $\mathrm{CuO}$ particles. The mean crystalite size of $\mathrm{CuO}$ is $28.3 \mathrm{~nm}$ calculated with Scherrer's equation [31] (shape factor 0.89) using the full width at half-maximum (FWHM) of the characteristic peak of $\mathrm{CuO}$ (111) $\left(2 \theta=38.92^{\circ}\right)$. The CO and NO adsorption spectra shown in Figure S2 (Supplementary Materials), however, indicate the presence of cationic copper species in small amount on the $\mathrm{Cu} / \mathrm{SiO}_{2}$ sample. 
The results from $\mathrm{XRD}$ and $\mathrm{CO} / \mathrm{NO}$ adsorption experiments picture the $\mathrm{Cu} / \mathrm{SiO}_{2}$ sample dominated with $\mathrm{CuO}$ nanoparticles accompanied by small amount of cationic $\mathrm{Cu}$ species.
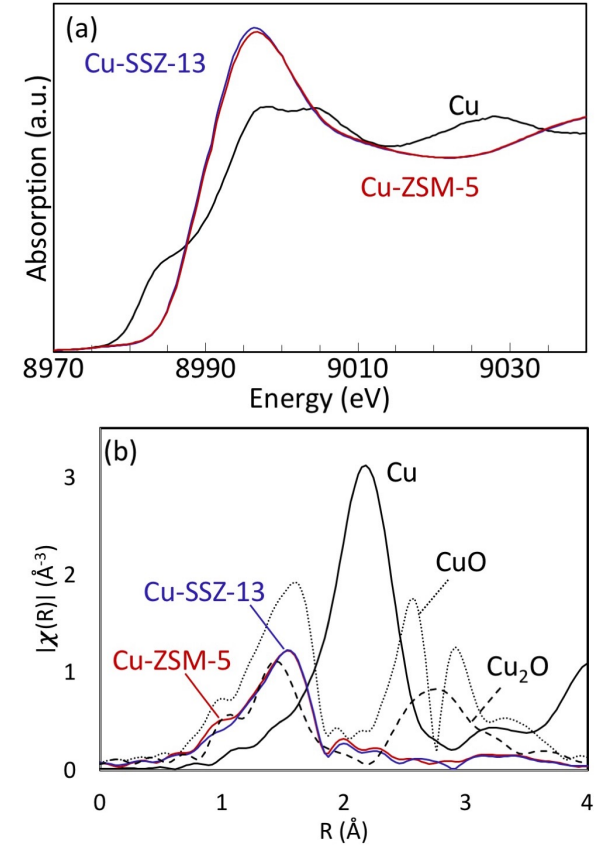

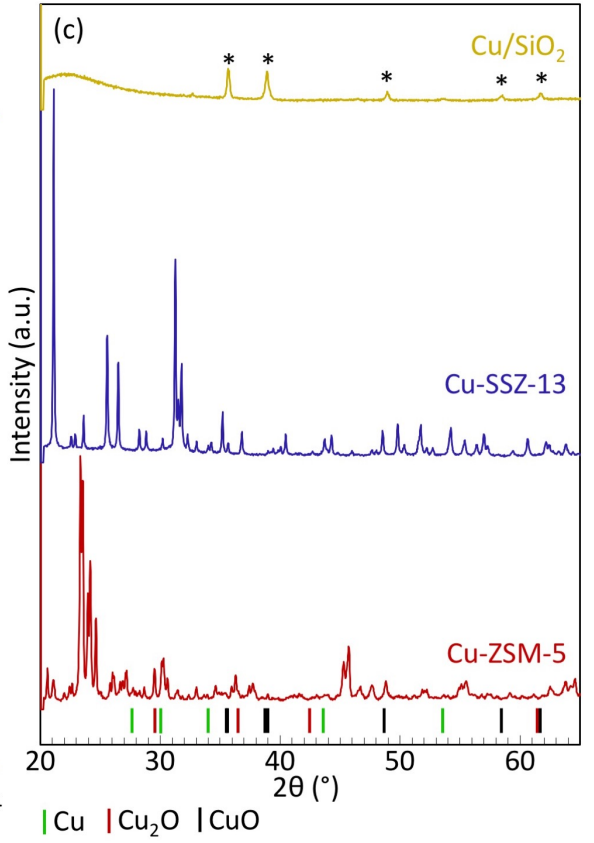

Figure 2. (a) XANES spectra of the Cu-ZSM-5 (red), Cu-SSZ-13 (blue) and Cu foil (black), as reference; (b) magnitude of Fourier transformed EXAFS spectra (k-weight = 2) of Cu-ZSM-5 (red), Cu-SSZ-13 (blue), $\mathrm{Cu}$ foil (solid black line), $\mathrm{Cu}_{2} \mathrm{O}$ (dashed black line, the Farrel Lytle database \#cu2o.514) [32] and $\mathrm{CuO}$ (dotted black line, the Farrel Lytle database \#cuoxop.027) [32]; (c) XRD patterns of the $\mathrm{Cu}-\mathrm{ZSM}-5, \mathrm{Cu}-\mathrm{SSZ}-13$ and $\mathrm{Cu} / \mathrm{SiO}_{2}$ samples; the characteristic reflections of the $\mathrm{CuO}$ crystalline structure are denoted with asterisks $\left(^{*}\right)$; the coloured bars at the bottom representing the reflections of $\mathrm{Cu}$ (green, SpringerMaterials sd_1928261), $\mathrm{Cu}_{2} \mathrm{O}$ (red, SpringerMaterials sd_1928262) and CuO (black, the American Mineralogist Crystal Structure Database \#0018812).

\subsection{In Situ IR Study of Methane Oxidation and Water Extraction}

Figure 3 presents the IR spectra during methane oxidation (solid lines) and water extraction (dashed lines) for all three samples. The presented spectra are focused on the $\mathrm{C}-\mathrm{H}$ and $\mathrm{C}=\mathrm{O}$ stretching vibration regions. Beside the gas phase methane $\left(3017 \mathrm{~cm}^{-1}\right)$ [33], $\mathrm{C}-\mathrm{H}$ stretching bands originated from adsorbed species are visible between 2800 and $3050 \mathrm{~cm}^{-1}$ for all three samples after methane oxidation. For the Cu-ZSM-5 sample, absorption bands of methoxy groups adsorbed on Brønsted acid sites $\left(2978 \mathrm{~cm}^{-1}\right)$ [34-37], formate on $\mathrm{Cu}\left(2906 \mathrm{~cm}^{-1}\right)$ [37] and $\mathrm{CO}$ on $\mathrm{Cu}\left(2157 \mathrm{~cm}^{-1}\right)$ [38] appear after $2 \mathrm{~h}$ exposure to methane. The evolution of these bands indicates that methane is oxidised and the oxidation products are stable on the sample surface. The low intensity of the bands, however, suggest low concentration of the adsorbed oxidised species. With longer exposure time to methane, $\mathrm{CO}$ accumulates on the copper species while the amount of $\mathrm{C}-\mathrm{H}$ containing species remains fairly constant. Similar features at the $\mathrm{C}-\mathrm{H}$ stretching vibrational region in IR spectra has been previously observed over $\mathrm{Cu}-\mathrm{MOR}$ upon exposure to methane at higher pressure [39]. After exposing the $\mathrm{Cu}-\mathrm{SSZ}-13$ and $\mathrm{Cu} / \mathrm{SiO}_{2}$ samples to methane for $2 \mathrm{~h}$, a peak at $2968 \mathrm{~cm}^{-1}$ arises for both samples while the peak at $2911 \mathrm{~cm}^{-1}$ is visible only for Cu-SSZ-13. Though it is expected that these bands are associated with adsorbed species originated from methane, the exact assignments are not apparent. Bands at wavenumbers close to $2968 \mathrm{~cm}^{-1}\left(v_{3}\right.$ mode) and $2911 \mathrm{~cm}^{-1}\left(v_{1}\right.$ mode) have been observed during methane adsorption on silica [40,41] and zeolites [41-43] due to dissosiative adsorption of methane. Moreover, methoxy groups adsorbed on Brønsted acid sites $\left(2968 \mathrm{~cm}^{-1}\right)$, extra framework $\mathrm{Al}\left(2978 \mathrm{~cm}^{-1}\right)$ and $\mathrm{Si}\left(2957 \mathrm{~cm}^{-1}\right)$ may contribute to the band at $2968 \mathrm{~cm}^{-1}$ for the Cu-SSZ-13 sample. It is clear that methane can adsorb dissociatively on the $\mathrm{Cu}-\mathrm{SSZ}-13$ and $\mathrm{Cu} / \mathrm{SiO}_{2}$ samples at $250{ }^{\circ} \mathrm{C}$. 
The absence of features in the $\mathrm{C}=\mathrm{O}$ stretching vibration region, however, suggests that the ability of these samples to catalyse further oxidation of methane at $250{ }^{\circ} \mathrm{C}$ is negligible. Interestingly, $\mathrm{CO}$ forms during methane oxidation over the $\mathrm{Cu}$ sites in the Cu-ZSM- 5 sample but not over the Cu-SSZ-13 sample. This can be due to the higher concentration of copper in the Cu-ZSM-5 sample, which is more than twice the amount of copper in the Cu-SSZ-13 sample. Moreover, a previous study has shown that $\mathrm{Cu}-\mathrm{SSZ}-13$ exhibits much higher methanol selectivity and lower $\mathrm{CO}$ or $\mathrm{CO}_{2}$ selectivity during catalytic methane oxidation compared to $\mathrm{Cu}-\mathrm{ZSM}-5$ with similar $\mathrm{Cu}$ loading [9]. It has been discovered that zeolites with the majority of the adsorption sites in 8-membered ring (MR) rather than in 6, 10 or 12 MRs (e.g., SSZ-13) can host higher concentrations of $\mathrm{Cu}$ species active for methanol formation $[24,44]$. Therefore, the lack of CO formation in the Cu-SSZ-13 sample can be a combination of low $\mathrm{Cu}$ loading that results in copper sites predominantly favouring formation of methanol rather than CO. Furthermore, the $\mathrm{Cu}$ species in $\mathrm{Cu}-\mathrm{SSZ}-13$ has been shown to be considerably more stable than $\mathrm{Cu}-\mathrm{ZSM}-5$ for which copper species may agglomerate to larger $\mathrm{Cu}$-oxo clusters that promote $\mathrm{CO}$ formation [45]. After water extraction (dashed lines in Figure 3), though most bands remain for the Cu-ZSM-5 and Cu-SSZ-13 samples, the bands related to methoxy on Brønsted acid sites $\left(2978 \mathrm{~cm}^{-1}\right)$, formate $\left(2906 \mathrm{~cm}^{-1}\right)$ and CO $\left(2157 \mathrm{~cm}^{-1}\right)$ decrease in intensity for Cu-ZSM-5, while the intensity of band at $2968 \mathrm{~cm}^{-1}$ decreases for Cu-SSZ-13. It is anticipated that the methoxy species adsorbed on the Cu-ZSM-5 and Cu-SSZ-13 samples react with water and desorb from the sample surface as methanol, leaving other more strongly adsorbed species, presumably methyl. For the $\mathrm{Cu} / \mathrm{SiO}_{2}$ sample, however, no obvious decrease in intensity is observed for the band at $2968 \mathrm{~cm}^{-1}$, which suggest that a trivial amount of methanol is produced during water extraction. These speculations are further supported by the activity studies discussed above.

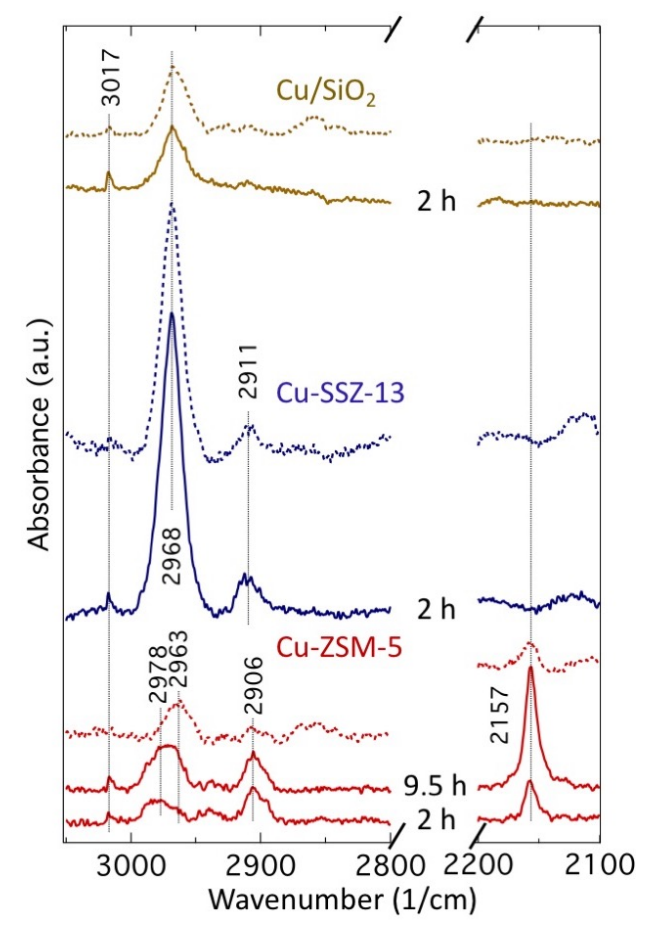

Figure 3. IR spectra of the Cu-ZSM-5, Cu-SSZ-13 and $\mathrm{Cu} / \mathrm{SiO}_{2}$ sample exposed to methane (solid line marked with exposure time) and after water extraction for $10 \mathrm{~min}$ (dashed line) at $250{ }^{\circ} \mathrm{C}$. The IR measurements were carried out at $1 \mathrm{~atm}$.

\subsection{Concluding Discussion}

In summary, $\mathrm{X}$-ray-based characterisation and infrared analysis of $\mathrm{CO} / \mathrm{NO}$ adsorption show that the prepared Cu-ZSM-5 and Cu-SSZ-13 samples contain cationic copper species. On the contrary, the $\mathrm{Cu} / \mathrm{SiO}_{2}$ sample is dominated by $\mathrm{CuO}$ particle sites and silica sites with the presence of cationic 
copper species in small amount. Methanol production is, to our knowledge for the first time, detected over the $\mathrm{Cu}-\mathrm{ZSM}-5, \mathrm{Cu}-\mathrm{SSZ}-13$ and $\mathrm{Cu} / \mathrm{SiO}_{2}$ monolith catalysts. The choice of sample form is different from that of the previous literatures which were conducted over powder or pellet samples. The monolith samples allow sufficient flow without detrimental pressure drop as to achieve reasonable time resolution in the FTIR gas phase analysis. The in situ infrared measurements reveal the formation of surface bound methoxy species as a likely important reaction intermediate during methane oxidation as well as the consumption of these methoxy species during water extraction, which is considerably more pronounced for the zeolitic systems. Hence, the higher methanol formation from Cu-ZSM-5 and $\mathrm{Cu}-\mathrm{SSZ}-13$ compared with $\mathrm{Cu} / \mathrm{SiO}_{2}$ can be attributed to the isolated $\mathrm{Cu}$ ions in consistence with previous suggestions $[5,10,11,14-16,46]$. Notably, here, the minor amount of formed methanol (3.5-6.4 $\mu \mathrm{mol} / \mathrm{g} \mathrm{Cu}$ ) over the $\mathrm{Cu} / \mathrm{SiO}_{2}$ sample regardless of oxidant is an interesting observation. Although the $\mathrm{Cu} / \mathrm{SiO}_{2}$ sample contains $\mathrm{CuO}$ particles as observed by XRD, one can not neglect the presence of copper ions possibly in the form of monomers, dimers or small ensembles. These ions are likely responsible for the formation of methanol in this case. The reason for the low amount of formed methanol may in this case be due to the low abundance of ionic copper species, or that the ionic copper species co-exist with larger $\mathrm{CuO}$ particles, which promote total oxidation such that the selectivity towards methanol becomes low. This speculation in turn suggests that the zeolite structure is not the only type of substrate that can host copper species active for DCMM as generally discussed hitherto. One may thus envisage that the choice of support may be more flexible than previously discussed such that catalyst design should primarily target the creation of small ensembles of copper ions, however, not necessarily contained in zeolites. In fact, low methanol production (less than $1 \mu \mathrm{mol} / \mathrm{g} \mathrm{Cu}$ ) has been previously observed over alumina containing $\mathrm{Cu} /$ silica system [7]. A very recent study also described the formation of active $\mathrm{Cu}$ species when proper conditions were used [47]. This is encouraging as for example ZSM-5 is a dehydration catalyst that is used to convert methanol to dimethyl ether (DME) in the well known methanol to gasoline (MTG) process [48] and therefore not the ideal substrate when striving for high methanol production. In fact, when much methanol is adsorbed, DME formation is evident already at $175^{\circ} \mathrm{C}$ [37], which is in the target temperature range suitable for DCMM. At present, however, the low methanol formation presented here and elsewhere allows for using ZSM-5 without any particular issues concerning DME formation.

\section{Experimental Section}

\subsection{Catalyst Preparation}

For this study, Cu-zeolite samples, Cu-ZSM-5 and Cu-SSZ-13, were prepared using aqueous ion-exchange [6]. The ion-exchange was carried out by mixing aqueous solutions of $\mathrm{Cu}\left(\mathrm{NO}_{3}\right)_{2}$ (0.1 M, $100 \mathrm{~mL} / \mathrm{g}$ zeolite) with H-ZSM-5 (Si/Al = 13.5, Akzo Nobel, Amsterdam, The Netherlands) or H-SSZ-13 ( $\mathrm{Si} / \mathrm{Al}=10$, synthesised according to the method described by Shishkin et al. $[49,50]$ ) at room temperature for $24 \mathrm{~h}$. The $\mathrm{pH}$ of the solution was kept at around 4.5 by addition of ammonia solution when necessary. After ion-exchange the slurry was filtered and the solid fraction was washed with Milli-Q water $(18 \mathrm{M} \Omega \cdot \mathrm{cm})$ and then dried at $120^{\circ} \mathrm{C}$ in air overnight. Inductively coupled plasma-sector field mass spectrometry (ICP-SFMS) gives a $\mathrm{Cu}$ loading of $2.8 \mathrm{wt}$. $\%$ for the Cu-ZSM-5 sample and $1.3 \mathrm{wt} . \%$ for the $\mathrm{Cu}-\mathrm{SSZ}-13$ sample. The $\mathrm{Cu} / \mathrm{SiO}_{2}$ sample was prepared using incipient wetness impregnation where an aqueous solution of $\mathrm{Cu}\left(\mathrm{NO}_{3}\right)_{2} \cdot 5 \mathrm{H}_{2} \mathrm{O}$ (Sigma-Aldrich, St. Louis, MO, USA, ACS reagent, $0.29 \mathrm{M}, 1.66 \mathrm{~mL} / \mathrm{g}$ silica) was slowly added to the silica support (Akzo Nobel, Kromasil, $200 \AA, 5 \mu \mathrm{m}$ ). The mixture was then instantly frozen by liquid nitrogen and freeze-dried over night before calcined in air at $350{ }^{\circ} \mathrm{C}$ for $3 \mathrm{~h}$. The $\mathrm{Cu}$ loading was $3.0 \mathrm{wt} . \%$ for the $\mathrm{Cu} / \mathrm{SiO}_{2}$ sample. Part of the Cu-ZSM-5, Cu-SSZ-13 and $\mathrm{Cu} / \mathrm{SiO}_{2}$ powder samples were used for wash-coating cordierite monolith substrates (Corning, New York, NY, USA, $400 \mathrm{cpsi}, \mathrm{L}=15 \mathrm{~mm}, \varnothing=13 \mathrm{~mm}$ ). For each catalyst sample, a slurry was prepared by mixing the powder catalyst sample with a binder (Sasol, Sandton, South Africa, Disperal P2) at a weight ratio of 80:20 in Milli-Q water. The calcined monolith substrates 
were coated with thin layers of the wash-coat until the added solid material on each substrate reached $0.2 \mathrm{~g}$. The monolith samples were finally calcined at $600{ }^{\circ} \mathrm{C}$ for $3 \mathrm{~h}$.

\subsection{Activity Test}

Catalytic activity tests of the prepared monolith samples were carried out using a chemical flow reactor system equipped with an FTIR analyser (MKS 2030 FTIR spectrometer) for continuous analysis of the effluent stream. The flow reactor consists of a horizontal quartz tube surrounded with an insulated metal coil for resistive heating. The catalyst temperature is measured by a type $\mathrm{K}$ thermocouple and controlled with a PID regulator (Eurotherm, Worthing, UK). The feed gas system consists of separate mass flow controllers (Bronkhorst Hi-Tech, Ruurlo, Netherlands, Low- $\Delta$ P-Flow) for the different gases and a water vapour generator that catalytically produces ultra-pure water vapour from high-purity $\mathrm{H}_{2}$ and $\mathrm{O}_{2}$ gases [51]. The activity test for direct conversion of methane to methanol was carried out through an activation-reaction-extraction sequential approach at $1 \mathrm{~atm}$. In this approach, the samples were first activated at $550{ }^{\circ} \mathrm{C}$ with the oxidant $\left(20 \%\right.$ vol $\mathrm{O}_{2}, 300 \mathrm{vol} \mathrm{ppm}$ $\mathrm{N}_{2} \mathrm{O}$ or $0.1 \%$ vol NO) for one hour before exposure to $2 \%$ vol $\mathrm{CH}_{4}$ at $150{ }^{\circ} \mathrm{C}$ for one hour. The products were then extracted with water vapour ( $4 \%$ vol for $\mathrm{Cu}-\mathrm{SSZ}-13$ and $\mathrm{Cu} / \mathrm{SiO}_{2}$, and $8 \%$ vol for $\mathrm{Cu}-\mathrm{ZSM}-5$ ) at $150{ }^{\circ} \mathrm{C}$. The methanol production was acquired by applying a peak area integration of the methanol concentration as measured by the gas phase FTIR analyser during the water extraction step. During this phase methanol was the main product together with a minor amount of $\mathrm{CO}_{2}$.

\subsection{Characterisation}

To correlate the methanol formation to relevant materials properties, $\mathrm{X}$-ray based characterisation was carried out. The local environment of copper was characterised by X-ray absorption spectroscopy (XAS) at beamline I811 at the MAX IV Laboratory, Lund, Sweden. Spectra were recorded at the Cu K-edge $(8979 \mathrm{eV})$ in fluorescence mode. The photon energy was calibrated using a $\mathrm{Cu}$ foil measured simultaneously with the sample. The X-ray absorption near edge structure (XANES) spectra were processed using the Athena software [52].

The crystal phases of the samples were determined by X-ray diffraction (XRD) using a Bruker XRD D8 Advance instrument with monochromatic $\mathrm{CuK}_{\alpha 1}$ radiation scanning $2 \theta$ from 20 to $60^{\circ}$ (step size $0.029^{\circ}$, dwell time $\left.1 \mathrm{~s}\right)$.

The in situ infrared spectroscopic measurements were carried out in diffuse reflectance mode using a VERTEX 70 spectrometer (Bruker) equipped with a liquid nitrogen cooled mercury cadmium telluride detector with the band width $600-12,000 \mathrm{~cm}^{-1}$, a Praying Mantis ${ }^{\mathrm{TM}}$ diffuse reflectance accessory and a high-temperature stainless steel reaction chamber (Harrick Scientific Products Inc., New York, NY, USA). All spectra were measured between 900 and $4000 \mathrm{~cm}^{-1}$ with a spectral resolution of $1 \mathrm{~cm}^{-1}$. The instrumental aperture was $3 \mathrm{~mm}$ wide with a four times sensitivity gain. About $85 \mu \mathrm{L}$ sample was loaded into the reaction chamber. Methane oxidation experiments were carried out for all three samples, i.e., $\mathrm{Cu}-\mathrm{ZSM}-5, \mathrm{Cu}-\mathrm{SSZ}-13$ and $\mathrm{Cu} / \mathrm{SiO}_{2}$, at $1 \mathrm{~atm}$. After pre-treatment with 500 vol ppm $\mathrm{N}_{2} \mathrm{O}$ at $550{ }^{\circ} \mathrm{C}$ for one hour, $2 \%$ vol of methane was fed to the sample at $250{ }^{\circ} \mathrm{C}$. Finally, the extraction step was carried out with $0.25 \mathrm{~g} / \mathrm{h}$ water in $\mathrm{Ar}$ at $250{ }^{\circ} \mathrm{C}$. All spectra were recorded in pure Ar. The backgrounds were taken in Ar at $250^{\circ} \mathrm{C}$ for each sample after the sample pre-treatment. Baseline subtraction is carried out for all spectra using the Igor Pro software. For the IR study, the set reaction temperature is $250^{\circ} \mathrm{C}$ instead of $150{ }^{\circ} \mathrm{C}$, which is used in the flow reactor. The reason for using this set temperature is that the cell design causes temperature gradients in the sample bed, such that the temperature in the volume probed by IR is considerably lower than the set temperature [53]. The set reaction temperature used in the present study results in similar temperatures for the flow-reactor experiments and the IR measurements. 


\section{Conclusions}

For copper-based catalytic materials, the direct conversion of methane to methanol requires ionic copper sites. Such sites are abundant in copper-exchanged zeolites, i.e., Cu-ZSM-5 and Cu-SSZ-13, which show clear methanol formation, but seem to exist also in $\mathrm{Cu} / \mathrm{SiO}_{2}$, although to a minor extent reflected by the minor methanol formation. In situ infrared spectroscopic measurements reveal that on these sites, the methanol formation proceeds through the formation/consumption of surface methoxy species, which are considered to be important intermediates in the direct conversion of methane to methanol.

Supplementary Materials: The following are available online at http:/ /www.mdpi.com/2073-4344/8/11/545/s1. Figure S1: XRD patterns of the H-ZSM-5 (red) and H-SSZ-13 (blue) samples, Figure S2: IR spectra after (a) CO adsorption and (b) $\mathrm{NO}$ adsorption on the Cu-ZSM-5, the Cu-SSZ-13 and the $\mathrm{Cu} / \mathrm{SiO}_{2}$ sample, Table S1: BET surface area $\left(\mathrm{S}_{\mathrm{BET}}\right)$, micropore volume and chemical composition of the Cu-ZSM-5, Cu-SSZ-13 and Cu/SiO 2 sample.

Author Contributions: X.W. carried out all experiments and is main responsible for preparing the paper; N.M.M. assisted in the XAS measurments; J.N. assisted in the XAS measurments; S.C. assisted in the set-up and operation of the XAS beam line; J.G. interpreted the XRD results; M.S. guided and discussed the experiments; P.-A.C. is principle investigator who conceived the idea and supervised the work.

Funding: This research was funded by the Swedish Research Council grant number 349-2013-567 and the Knut and Alice Wallenberg foundation grant number 2015.0058.

Acknowledgments: The authors thank MAX IV Laboratory (Lund, Sweden) for providing the beamtime. This work is financially supported by the Swedish Research Council through the Röntgen-Ångström Clusters [No. 349-2013-567], the Knut and Alice Wallenberg foundation [No. 2015.0058], as well as the Competence Centre for Catalysis, which is hosted by Chalmers University of Technology and financially supported by the Swedish Energy Agency and the member companies: AB Volvo, ECAPS AB, Johnson Matthey AB, Preem AB, Scania CV AB, Umicore Denmark ApS and Volvo Car Corporation AB.

Conflicts of Interest: The authors declare no conflict of interest.

\section{References}

1. Goldberg, I.; Rokem, J.S. Biology of Methylotrophs; Butterworth-Heinemann: Stoneham, MA, USA, 1991; p. 3.

2. Woodland, M.P.; Dalton, H. Purification of Component A of the Soluble Methane Monooxygenase of Methylococcus capsulatus (Bath) by High-pressure Gel-permeation Chromatography. Anal. Biochem. 1984, 139, 459-462. [CrossRef]

3. Ji, Y.; Mao, G.; Wang, Y.; Bartlam, M. Structural Insights into Diversity and N-alkane Biodegradation Mechanisms of Alkane Hydroxylases. Front. Microbiol. 2013, 4, 1-13. [CrossRef] [PubMed]

4. Citek, C.; Gary, J.B.; Wasinger, E.C.; Stack, T.D. Chemical Plausibility of Cu-(III) with Biological Ligation in pMMO. J. Am. Chem. Soc. 2015, 137, 6991-6994. [CrossRef] [PubMed]

5. Vanelderen, P.; Hadt, R.G.; Smeets, P.J.; Solomon, E.I.; Schoonheydt, R.A.; Sels, B.F. Cu-ZSM-5: A Biomimetic Inorganic Model for Methane Oxidation. J. Catal. 2011, 284, 157-164. [CrossRef] [PubMed]

6. Beznis, N.V.; Weckhuysen, B.M.; Bitter, J.H. Cu-ZSM-5 Zeolites for the Formation of Methanol from Methane and Oxygen: Probing the Active Sites and Spectator Species. Catal. Lett. 2010, 138, 14-22. [CrossRef]

7. Groothaert, M.H.; Smeets, P.J.; Sels, B.F.; Jacobs, P.A.; Schoonheydt, R.A. Selective Oxidation of Methane by the Bis( $\mu$-oxo)dicopper Core Stabilized on ZSM-5 and Mordenite Zeolites. J. Am. Chem. Soc. 2005, 127, 1394-1395. [CrossRef] [PubMed]

8. Narsimhan, K.; Iyoki, K.; Dinh, K.; Román-Leshkov, Y. Catalytic Oxidation of Methane into Methanol over Copper-Exchanged Zeolites with Oxygen at Low Temperature. ACS Cent. Sci. 2016, 2, 424-429. [CrossRef] [PubMed]

9. Ipek, B.; Lobo, R.F. Catalytic Conversion of Methane to Methanol on Cu-SSZ-13 Using $\mathrm{N}_{2} \mathrm{O}$ as Oxidant. Chem. Commun. 2016, 52, 13401-13404. [CrossRef] [PubMed]

10. Woertink, J.S.; Smeets, P.J;; Groothaert, M.H.; Vance, M.A.; Sels, B.F.; Schoonheydt, R.A.; Solomon, E.I. A $\left[\mathrm{Cu}_{2} \mathrm{O}\right]^{2+}$ Core in Cu-ZSM-5, the Active Site in the Oxidation of Methane to Methanol. Proc. Natl. Acad. Sci. USA 2009, 106, 18908-18913. [CrossRef] [PubMed] 
11. Smeets, P.J.; Groothaert, M.H.; Schoonheydt, R.A. Cu Based Zeolites: A UV-vis Study of the Active Site in the Selective Methane Oxidation at Low Temperatures. Catal. Today 2005, 110, 303-309. [CrossRef]

12. Alayon, E.M.C.; Nachtegaal, M.; Bodi, A.; Ranocchiari, M.; van Bokhoven, J.A. Bis( $\mu$-oxo) Versus Mono( $\mu$-oxo)dicopper Cores in a Zeolite for Converting Methane to Methanol: An In Situ XAS and DFT Investigation. Phys. Chem. Chem. Phys. 2015, 17, 7681-7693. [CrossRef] [PubMed]

13. Grundner, S.; Markovits, M.A.C.; Li, G.; Tromp, M.; Pidko, E.A.; Hensen, E.J.M.; Jentys, A.; Sanchez-Sanchez, M.; Lercher, J.A. Single-site Trinuclear Copper Oxygen Clusters in Mordenite for Selective Conversion of Methane to Methanol. Nat. Commun. 2015, 6, 1-9. [CrossRef] [PubMed]

14. Tsai, M.L.; Hadt, R.G.; Vanelderen, P.; Sels, B.F.; Schoonheydt, R.A.; Solomon, E.I. $\left[\mathrm{Cu}_{2} \mathrm{O}\right]^{2+}$ Active Site Formation in Cu-ZSM-5: Geometric and Electronic Structure Requirements for $\mathrm{N}_{2} \mathrm{O}$ Activation. J. Am. Chem. Soc. 2014, 136, 3522-3529. [CrossRef] [PubMed]

15. Li, G.; Vassilev, P.; Sanchez-Sanchez, M.; Lercher, J.A.; Hensen, E.J.M.; Pidko, E.A. Stability and Reactivity of Copper Oxo-clusters in ZSM-5 Zeolite for Selective Methane Oxidation to Methanol. J. Catal. 2016, 338, 305-312. [CrossRef]

16. Kulkarni, A.R.; Zhao, Z.J.; Siahrostami, S.; Nørskov, J.K.; Studt, F. Monocopper Active Site for Partial Methane Oxidation in Cu-Exchanged 8MR Zeolites. ACS Catal. 2016, 10, 6531-6536. [CrossRef]

17. Feig, A.L.; Lippard, S.J. Reactions of Non-Heme Iron(II) Centers with Dioxygen in Biology and Chemistry. Chem. Rev. 1994, 94, 759-805. [CrossRef]

18. Dubkov, K.A.; Sobolev, V.I.; Talsi, E.P.; Rodkin, M.A.; Watkins, N.H.; Shteinman, A.A.; Panov, G.I. Kinetic Isotope Effects and Mechanism of Biomimetic Oxidation of Methane and Benzene on FeZSM-5 Zeolite. J. Mol. Catal. A Chem. 1997, 123, 155-161. [CrossRef]

19. Tomkins, P.; Mansouri, A.; Bozbag, S.E.; Krumeich, F.; Park, M.B.; Alayon, E.M.; Ranocchiari, M.; van Bokhoven, J.A. Isothermal Cyclic Conversion of Methane into Methanol over Copper-Exchanged Zeolite at Low Temperature. Angew. Chem. Int. Ed. 2016, 55, 5467-5471. [CrossRef] [PubMed]

20. Arvidsson, A.A.; Zhdanov, V.P.; Carlsson, P.A.; Grönbeck, H.; Hellman, A. Metal Dimer Sites in ZSM-5 Zeolite for Methane-to-Methanol Conversion from First-Principles Kinetic Modelling: Is the [Cu-O-Cu $]^{2+}$ Motif Relevant for Ni, Co, Fe, Ag, and Au? Catal. Sci. Technol. 2017, 7, 1470-1477. [CrossRef]

21. Argauer, R.J.; Landolt, G.R. Crystalline Zeolite ZSM-5 and Method of Preparing the Same. U.S. Patent 3,702,886, 14 November 1972.

22. Hadjiivanov, K. Advances in Catalysis; Academic Press: New York, NY, USA, 2014; Volume 57, p. 101.

23. Oord, R.; Schmidt, J.E.; Weckhuysen, B.M. Methane-to-methanol Conversion over Zeolite Cu-SSZ-13, and Its Comparison with the Selective Catalytic Reduction of $\mathrm{NO}_{\mathrm{x}}$ with $\mathrm{NH}_{3}$. Catal. Sci. Technol. 2018, 8, 1028-1038. [CrossRef]

24. Ipek, B.; Wulfers, M.J.; Kim, H.; Göltl, F.; Hermans, I.; Smith, J.P.; Booksh, K.S.; Brown, C.M.; Lobo, R.F. Formation of $\left[\mathrm{Cu}_{2} \mathrm{O}_{2}\right]^{2+}$ and $\left[\mathrm{Cu}_{2} \mathrm{O}\right]^{2+}$ toward C-H Bond Activation in Cu-SSZ-13 and Cu-SSZ-39. ACS Catal. 2017, 7, 4291-4303. [CrossRef]

25. Pappas, D.K.; Borfecchia, E.; Dyballa, M.; Pankin, I.A.; Lomachenko, K.A.; Martini, A.; Signorile, M.; Teketel, S.; Arstad, B.; Berlier, G.; et al. Methane to Methanol: Structure-Activity Relationships for Cu-CHA. J. Am. Chem. Soc. 2017, 139, 14961-14975. [CrossRef] [PubMed]

26. Lamberti, C.; Bordiga, S.; Salvalaggio, M.; Spoto, G.; Zecchina, A. XAFS, IR, and UV-Vis Study of the Cu Environment in CuI-ZSM-5. J. Phys. Chem. B 1997, 101, 344-360. [CrossRef]

27. Groothaert, M.H.; Bokhoven, J.A.V.; Battiston, A.A.; Weckhuysen, B.M.; Schoonheydt, R.A. Bis( $\mu$-oxo)dicopper in Cu-ZSM-5 and Its Role in the Decomposition of NO: A Combined in Situ XAFS, UV-Vis-Near-IR, and Kinetic Study. J. Am. Chem. Soc. 2002, 125, 7629-7640. [CrossRef] [PubMed]

28. de Carvalho, M.C.A.; Passos, F.B.; Schmal, M. Quantification of metallic area of high dispersed copper on ZSM-5 catalyst by TPD of $\mathrm{H}_{2}$. Catal. Commun. 2002, 3, 503-509. [CrossRef]

29. Martini, A.; Borfecchia, E.; Lomachenko, K.A.; Pankin, I.A.; Negri, C.; Berlier, G.; Beato, P.; Falsig, H.; Bordiga, S.; Lamberti, C. Composition-driven Cu-speciation and reducibility in Cu-CHA zeolite catalysts: A multivariate XAS/FTIR approach to complexity. Chem. Sci. 2017, 8, 6836-6851. [CrossRef] [PubMed]

30. International Zeolite Association Webpage. Available online: http:/ / europe.izastructure.org (accessed on 14 March 2017).

31. Scherrer, P. Bestimmung der Größe und der Inneren Struktur von Kolloidteilchen Mittels Röntgenstrahlen. Nachr. Ges. Wiss. Göttingen Math. Phys. Klasse 1918, 3, 98-100. 
32. The Farrel Lytle Database. Available online: http://ixs.csrri.iit.edu/database/data/Farrel_Lytle_data/ (accessed on 18 May 2017).

33. Manzanares, C.; Brock, A.; Peng, J.; Blunt, V.M. Vibrational Spectroscopy of C-H Bonds of Methane and Tetramethylsilane in Liquid Argon Solutions. Chem. Phys. Lett. 1993, 207, 159-166. [CrossRef]

34. Kung, M.C.; Lin, S.S.Y.; Kung, H.H. In situ Infrared Spectroscopic Study of $\mathrm{CH}_{4}$ Oxidation Over Co-ZSM-5. Top. Catal. 2012, 55, 108-115. [CrossRef]

35. Wood, B.R.; Reimer, J.A.; Bell, A.T.; Janicke, M.T.; Ott, K.C. Methanol Formation on Fe/Al-MFI via the Oxidation of Methane by Nitrous Oxide. J. Catal. 2004, 225, 300-306. [CrossRef]

36. Campbell, S.M.; Jiang, X.Z.; Howe, R.F. Methanol to Hydrocarbons: Spectroscopic Studies and the Significance of Extra-Framework Aluminium. Microporous Mesoporous Mater. 1999, 29, 91-108. [CrossRef]

37. Wang, X.; Arvidsson, A.A.; Cichocka, M.O.; Zou, X.; Martin, N.M.; Nilsson, J.; Carlson, S.; Gustafson, J.; Skoglundh, M.; Hellman, A.; et al. Methanol Desorption from Cu-ZSM-5 Studied by In Situ Infrared Spectroscopy and First-Principles Calculations. J. Phys. Chem. C 2017, 121, 27389-27398. [CrossRef]

38. Hadjiivanov, K.I.; Kantcheva, M.M.; Klissurski, D.G. IR Study of CO Adsorption on Cu-ZSM-5 and $\mathrm{CuO} / \mathrm{SiO}_{2}$ Catalysts: $\delta$ and $\pi$ Components of the $\mathrm{Cu}^{+}-\mathrm{CO}$ Bond. J. Chem. Soc. Faraday Trans. 1996, 92, 4595-4600. [CrossRef]

39. Sushkevich, V.L.; Palagin, D.; Ranocchiari, M.; van Bokhoven, J.A. Selective anaerobic oxidation of methane enables direct synthesis of methanol. Science 2017, 356, 523-527. [CrossRef] [PubMed]

40. Permenov, D.G.; Radzig, V.A. Mechanisms of Heterogeneous Processes in the System $\mathrm{SiO}_{2}+\mathrm{CH}_{4}$ : I. Methane Chemisorption on a Reactive Silica Surface. Kinet. Catal. 2004, 45, 14-23. [CrossRef]

41. Chen, L.; Lin, L.; Xu, Z.; Zhang, T.; Liang, D. Interaction of Methane with Surfaces of Silica, Aluminas and HZSM-5 Zeolite. A Comparative FT-IR Study. Catal. Lett. 1995, 35, 245-258. [CrossRef]

42. Kazansky, V.B. State and Properties of Ion-exchanged Cations in Zeolites: 2. IR Spectra and Chemical Activation of Adsorbed Methane. Kinet. Catal. 2014, 55, 737-747. [CrossRef]

43. Kazanskii, V.; Serykh, A.; Bell, A. Diffuse-reflectance IR Spectra of Methane Adsorbed on NaZSM-5 and HZSM-5 zeolites. Kinet. Catal. 2002, 43, 419-426. [CrossRef]

44. Park, M.B.; Ahn, S.H.; Mansouri, A.; Ranocchiari, M.; van Bokhoven, J.A. Comparative Study of Diverse Copper Zeolites for the Conversion of Methane into Methanol. ChemCatChem 2017, 9, 3705-3713. [CrossRef]

45. Deka, U.; Lezcano-Gonzalez, I.; Weckhuysen, B.M.; Beale, A.M. Local Environment and Nature of Cu Active Sites in Zeolite-Based Catalysts for the Selective Catalytic Reduction of $\mathrm{NO}_{\mathrm{x}}$. ACS Catal. 2013, 3, 413-427. [CrossRef]

46. Yumura, T.; Hirose, Y.; Wakasugi, T.; Kuroda, Y.; Kobayashi, H. Roles of Water Molecules in Modulating the Reactivity of Dioxygen-Bound Cu-ZSM-5 toward Methane: A Theoretical Prediction. ACS Catal. 2016, 6, 2487-2495. [CrossRef]

47. Bozbag, S.E.; Sot, P.; Nachtegaal, M.; Ranocchiari, M.; van Bokhoven, J.A.; Mesters, C. Direct Stepwise Oxidation of Methane to Methanol over $\mathrm{Cu}_{-} \mathrm{SiO}_{2}$. ACS Catal. 2018, 8, 5721-5731. [CrossRef]

48. Keil, F.J. Methanol-to-hydrocarbons: Process Technology. Microporous Mesoporous Mater. 1999, $29,49-66$. [CrossRef]

49. Shishkin, A.; Kannisto, H.; Carlsson, P.A.; Härelind, H.; Skoglundh, M. Synthesis and Functionalization of SSZ-13 as an $\mathrm{NH}_{3}$-SCR Catalyst. Catal. Sci. Technol. 2014, 4, 3917-3926. [CrossRef]

50. Zones, S.I. Zeolite SSZ-13 and Its Method of Preparation. U.S. Patent 4,544,538, 1 October 1985.

51. Velin, P.; Stenman, U.; Skoglundh, M.; Carlsson, P.A. Portable Device for Generation of Ultra-pure Water Vapor Feeds. Rev. Sci. Instrum. 2017, 88, 115102. [CrossRef] [PubMed]

52. Ravel, B.; Newville, M. ATHENA, ARTEMIS, HEPHAESTUS: Data Analysis for X-ray Absorption Spectroscopy Using IFEFFIT. J. Synchrotron Rad. 2005, 12, 537-541. [CrossRef] [PubMed]

53. Li, H.; Rivallan, M.; Thibault-Starzyk, F.; Travert, A.; Meunier, F.C. Effective Bulk and Surface Temperatures of the Catalyst Bed of FT-IR Cells Used for in situ and operando Studies. Phys. Chem. Chem. Phys. 2013, 15, 7321-7327. [CrossRef] [PubMed]

(C) 2018 by the authors. Licensee MDPI, Basel, Switzerland. This article is an open access article distributed under the terms and conditions of the Creative Commons Attribution (CC BY) license (http:/ / creativecommons.org/licenses/by/4.0/). 